\title{
SGT. GUY GILLETTE AND CHEROKEE'S "GALLANT CO. M" IN THE SPANISH AMERICAN WAR
}

\author{
by $\mathrm{W}$. Ardell Stelck \\ Northridge, California
}

Dr. Stelck is a native of Correctionville, Iowa and is presently a Professor of History at San Fernando Valley State College, Northridge, California. Dr. Stelck is currently at work on a biography of Senator Guy M. Gillette.

In the early dawn of April 26, 1898, "boys in blue" began to appear on the streets of Cherokee, Iowa. They were soldiers of Co. M of the Iowa National Guard, hurrying to early muster. Four days earlier Congress had voted a war resolution. Cherokee and her "gallant Co. M" were responding to the President's call. "Hundreds of flags floated in the morning breeze. Bunting fluttered gaily from almost every building on the principal streets and the town was dressed as for a gala day." Everywhere "people were all astir."

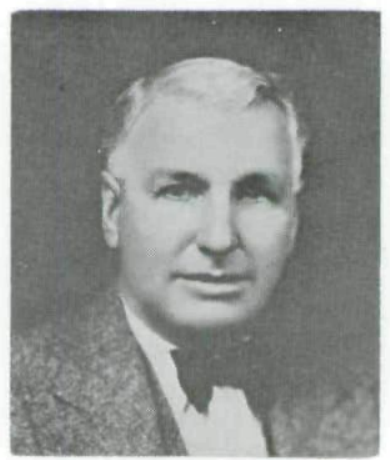

Guy Gillette

One of the young men reporting in early at the armory was Guy Mark Gillette, who, at nineteen, held the rank of sergeant in Co. M. His tour of duty in the SpanishAmerican War was destined to mark the beginning of a long and distinguished record of service to his fellow-Iowans and to his country.

Commanding Co. M was Capt. Edward A. Kreger, a native of Keota, Iowa. He had earned a Bachelor of Science degree at Iowa State College in Ames in 1890, studied law for a year at Iowa City and then served for four years as high school principal and superintendent of the Cherokee schools. But for Kreger a legal career had seemed to be more attractive than a career in education; so he completed his studies at the Iowa College of Law in Des Moines. In 1897, the Iowa bar admitted him to membership, 
and he opened a law practice in Cherokee.

In the Cadet Corps at Iowa State, Kreger had moved from private through the ranks to major. Soon after arriving in Cherokee, he had organized a group of men into Co. M, Fourth Regiment, Iowa National Guard, recruiting many high school boys.

Able, respected, and popular, "Ed" Kreger's service as school administrator, teacher and Guard commander touched the lives of many people in Cherokee. Among them was Guy Gillette, "a tall, gangling country boy, fourteen years of age," who lived out on the west side of town. With the knowledge and consent of his father, but not of his mother, Gillette enlisted in the Guard unit in the spring of 1893.

Young Gillette soon experienced the anguish of a Guardsman's historic role - violent confrontation with fellowcitizens. In 1894 the famous Pullman Strike in Chicago ex-

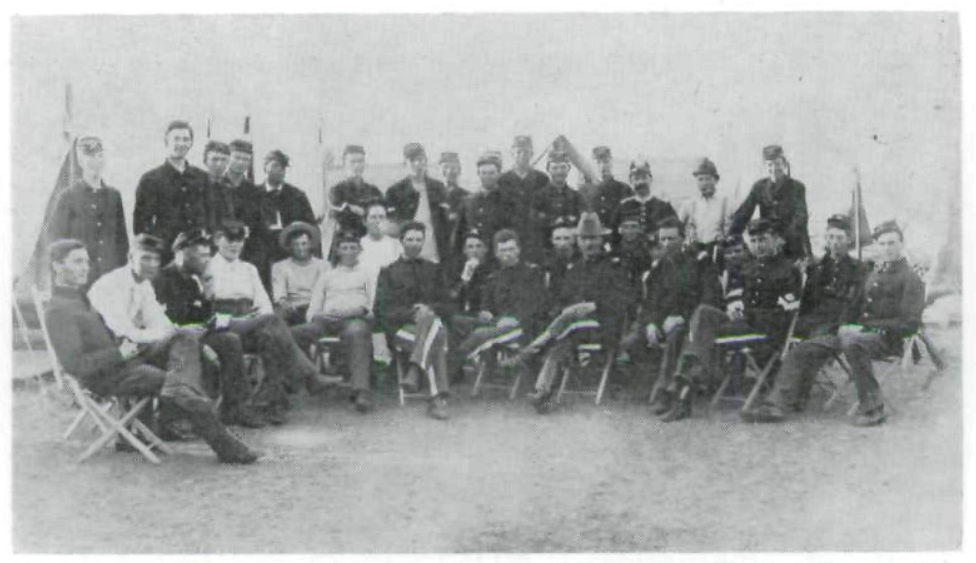

from the collection of N. L. Stiles

Company $\mathrm{M}$ at Sioux City riots.

Standing, left to right: W. D. Faus, Harry Doods, Fred Russell, Wm. Shardlow, C. H. Hall, Fred Littlefield, J. H. Glasson, John Doggett, Elmer Kennedy, Jim Sheldon, John Couch, Guy Gillette.

Seated, left to right: John Liffring, Jim Dowding, Harry Maltby, John Chapman, McMasters, Harry Barkley, Chas. Durkee, Fred Denslow, Claude Pingrey, Mark Hobart, Art. Kennedy, Capt. A. E. Kreger, Chas. Cutler, Chas. Lauer, Geo. Roddis, Chas. Roddis, Geo. Schuster, Estel Shaw, Redeisel. 
tended westward over the Illinois Central Railroad and came "to a head" at Sioux City, Iowa, on the Fourth of July. Private Gillette was called out of bed at three in the morning and celebrated that Independence Day holding a rifle with fixed bayonet, escorting U. S. Mail cars from the suburb of Leeds through a rough and hostile mob to the union depot in Sioux City.

Except for the Sioux City incident Gillette's early service in the National Guard was routine. Cherokee managed to remain aloof from much of the turmoil that disrupted American society during the nineties. As the years passed, Co. M. paraded and drilled, Gillette moved up to sergeant, and the United States inadvertently groomed herself for an official debut as a world power.

The world wide depression of 1895 brought economic chaos to Cuba. The Spanish ruled the island harshly and discontent was chronic. Cubans paid heavy taxes but never felt any improvement in their daily lives. When the depression drove the price of sugar down, Cuban workers in the canefields and sugar mills lost their jobs or were put on starvation wages. In Feb., 1895 thousands of Cubans raised the cry for independence. They formed an insurgent government and army and put the torch to canefields and sugar mills.

Spain countered with more troops and Gen. "Butcher" Weyler, who herded loyal Cubans into concentration camps and shot those who stayed out. The war dragged on for three years. Agriculture and industry ground to a standstill and death stalked the island.

The sympathy of the American people went out to the Cubans in their struggle for independence. When their terrible suffering was made to appear even worse by the sensational American "yellow press," America responded with food and medicine and the venerable Clara Barton.

But relief of the suffering was not enough. Some influential clergymen and politicians began to pressure their government for intervention with force although many businessmen and some politicians opposed intervention.

Genuine sympathy for Cubans accounted in part for growing American demands that the matter be settled by 
war if necessary. But alongside this sympathetic outreaching, feelings of anxiety about America's fitness to survive were present in the minds of many Americans. Civic corruption, economic depression, the wave of new and strange immigrants from southern and eastern Europe, business monopoly, slums, labor violence, the farmers in revolt, all seemed to suggest a growing decadence, a loss of mission in American life. Perhaps war could restore America's fighting edge, remove self-doubt. Militarily weak Spain had become an attractive adversary.

Pressure for intervention on cautious President McKinley became irresistible. Guy Gillette, who had just finished high school, shared with the people of Cherokee general dissatisfaction with McKinley's hesitancy to act.

Following riots in Havana in Dec., 1897, the President sent the battleship Maine to Havana harbor as a safeguard for American lives and property. Two hundred and sixty bluejackets died when a terrific explosion sank the Maine at her anchorage. The responsibility for the destruction of the Maine has never been clearly revealed, but the American public assumed it could only have been sunk by an agent of Spain.

On April 20, 1898 Congress demanded that Spain relinquish her authority and government in Cuba. The United States Minister to Spain, Stewart L. Woodford, working desperately for a settlement short of war, had cabled from Madrid that he believed he could obtain a solution satisfactory to all parties. Diplomacy pointed the way out, but the American people were not to be appeased. On April 25, 1898, Congress declared war.

A group of refugees, the Cuban junta, could claim some of the credit for molding American public opinion sympathetic to the Cuban cause and in support of armed intervention. From a "Cuban Legation" in the Raleigh Hotel in Washington, D.C. and from its general headquarters at 120 Front Street, New York, the junta exploited every opportunity for space in newspapers throughout the country and the Midwestern papers gave unstintedly of their space and support. The Sioux City Journal, a newspaper widely read throughout 
Northwest Iowa, received and printed much of the material that the Cuban propagandists distributed.

As America moved toward war with Spain, Cherokee readers found good coverage of developments concerning Cuba in their local newspapers, and in the larger "city papers" they could read the more sensational stories provided by the Cuban junta. When the Maine exploded and sank, the reaction in Cherokee matched the indignation of the rest of the country. Who but the Spanish could be responsible? Guy Gillette, at eighty-eight years of age, who had celebrated his nineteenth birthday just a week before the Maine explosion, smiled as he recalled "Was I a hawk! We young fellows were ready to blast the Spaniards right out of this hemisphere!"

When Congress declared war, Iowa citizens responded enthusiastically. In anticipation of such an eventuality the Iowa General Assembly had placed $\$ 500,000$ at the disposal of the Governor. President McKinley asked Iowa for three regiments of infantry and two batteries of artillery. Iowans thought that McKinley's request was too modest; the State had four organized regiments of infantry and popular opinion demanded that they be accepted for service. The War Department gave in and called up four regiments, limiting each to 834 men and omitting batteries.

Following President McKinley's call for troops, Captain Kreger had, for several days, held his company in readiness for immediate departure. During this time almost every train from every direction brought to Cherokee a number of young men from neighboring towns who wanted to enlist. Co. M. soon had its full quota and the ones that could not be taken were enrolled as a reserve from which to recruit. For the remaining days before their departure, the men of Co. M enjoyed the adulation Cherokee showered upon them.

On Sunday, April 24, Co. M went in a body to the Presbyterian Church in Cherokee and heard a sermon which the Cherokee Times described as "able . . . particularly fitting for the occasion." The choir sang "God Be With You Till We Meet Again." The congregation stood as the company marched out of the church while the big organ pealed forth 
the strains of "Three Cheers for the Red, White and Blue."

During the afternoon five thousand people gathered at Nokomis Park. While the Cherokee band played, Co. M gave an exhibition of guard mount, close order drill, and formation in open order throwing out skirmish lines commanded by the sound of the whistle. The troops performed so perfectly that the crowd many times broke into enthusiastic applause. For an enthralled Cherokee Times' reporter "it was not only impressive - but beautiful!" Before the exhibition ended orders arrived setting the next Tuesday as departure date.

The early morning hours of Tuesday, April 26, passed quickly at the armory. Friends and relatives came by for final goodbyes. F. J. Stanosheck stopped to present a written agreement offering fifty dollars for the first Spanish flag captured by a member of Co. M. At 11:00 o'clock, headed by the band, the boys, knapsacks and blankets on their backs and guns at their shoulders, marched to the Masonic Hall. After a short informal reception a "substantial meal" was served. "It was a sad sight there," the Times recorded. Several good citizens "tried to make music but. . their hearts were up in their throats and it was hard work." Guy Gillette's

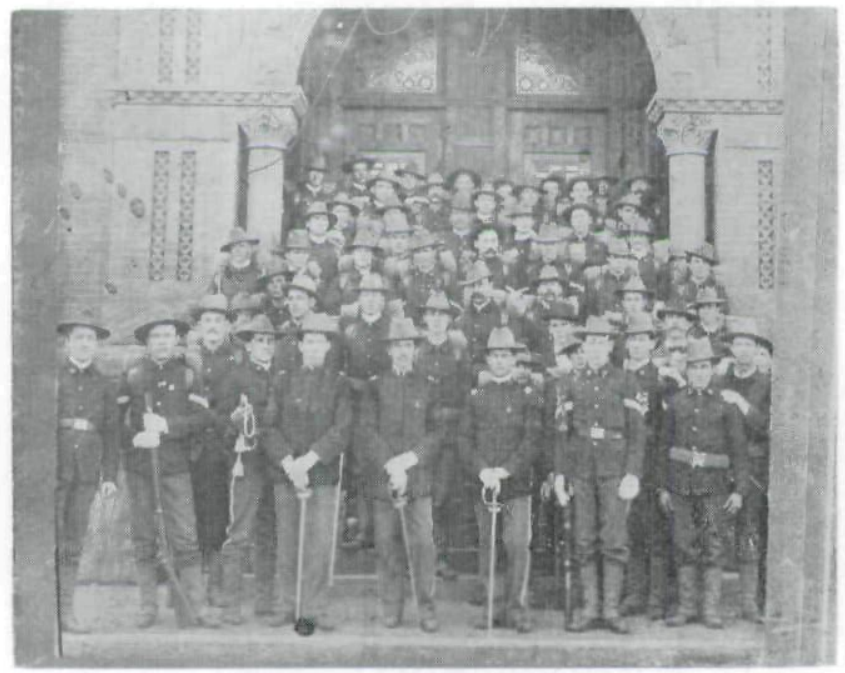

from the collection of N. L. Stiles Co. M. in dress uniform on steps of Opera House at Chrokee. 
recollections were more specific. A school teacher sang a well-known song of the sobbing Civil War days. Sergeant Gillette remembered her with mixed emotions. The title of her song stuck in his memory - "Goodby, Dear Mother! You Will Never Press Me To Your Heart Again!” When she started to sing, mothers began to sob and a few guardsmen sniffled. "My gosh, it was a heck of a mess before we got out of there," Gillette recalled.

After the meal a procession formed for the march to the depot. It was headed by Mayor Rankins who was followed by Beals Dixon and Garland Goldie carrying the national colors and those of the Cuban Republic. The band came next followed by seventy-five or eighty veterans of the Civil War who made an appropriate escort for the young soldiers. After the veterans came a large party of young ladies wearing sashes and carrying flags and behind them marched Co. M in service uniforms. The enormous crowd that had convened in town cheered wildly as they passed.

War fever gripped the populace. Schools had adjourned and business houses were closed. Sidewalks were blocked with spectators. For half an hour the throng had been gathering at the depot and by the time the procession reached it a crowd of 2500 was wedged in closely on the platform and grounds. The band played and young ladies sang patriotic songs. Everyone joined in rousing cheers for "our brave boys," as the soldiers sought the chance to bid their relatives and sweethearts goodbye. When the company finally lined up to get aboard the Illinois Central they twice shouted in unison the words emblazoned on a huge banner stretched across their railroad car: "Remember the Maine!" and the crowd immediately responded with three rousing cheers for Co. M. From atop a nearby freight car a "drunken brakeman" spotting young Gillette sent him out to face the Spaniards with a shout, "go get 'em Guy!

the scene: our loyal hearts!" A Times reporter recorded

Amid the shouts and cheers, the wailing and tears, and the music of the drum corps, the train pulled slowly out of the yards, watched longingly by thousands of dimmed eyes. 
Surely Co. M was destined to rid the Western Hemisphere of the decadent Spanish!

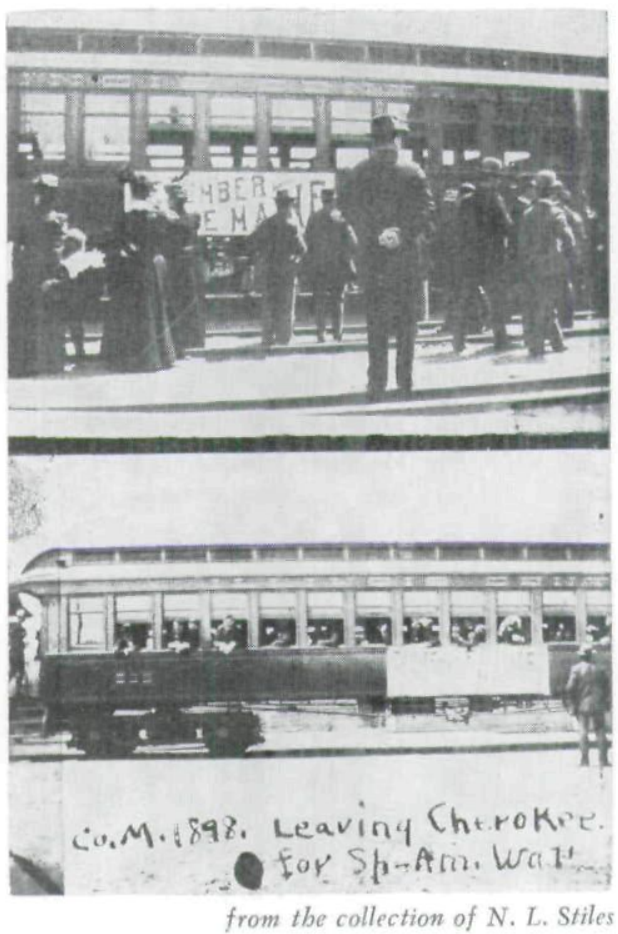

A Cherokee youngster named Ralph Block and his father were in the throng. Block was later to enjoy a long and distinguished career as a diplomat, editor, critic, and writer but he never forgot the drama of that exciting day in Cherokee. "This is the last war you will ever see," father told son. Ralph Block was just nine years old at the time, but he never forgot his father's words and recalled them nearly seven decades later in a letter to his old friend Guy Gillette, concluding, "such visible trust in the mechanics of living is not visible today." But in Cherokee on that bright April day in 1898 the primary consideration was not the future; it was getting on with the noble task of punishing Spain for mistreating her Cuban colony. 
The evolutionary philosophy of Charles Darwin, the English naturalist, was very popular throughout America at the end of the nineteenth century. Darwin was concerned primarily with biology, but men like J. S. Crawford of Cherokee's Herald took Darwin's hypothesis concerning survival of the fittest in the struggle for existence and translated it into a struggle among nations:

The young men .... can't always live and move and act in the same little town. They must see the world. They must get into its conflict. . . share its hardship . . . Action, conflict, guns, cannon, swords, battle, war, blood, prisoners of war, wounds, death, disaster, and destruction-these are the prices of heroic men, they are the epic field of nations ... No, peace never makes great men. It is war, conflict, terrible war, terrific war, that makes men. Peace decays, repose destroys, ease kills. Better a thousand times your boy or lover should die with a bayonet thrust than that his energies and talent should go into decay for want of exercise. This war may be his opportunity.

It was this kind of sabre-rattling rhetoric that made the early stages of the Spanish conflict so purposeful and so glamourous. The enthusiastic receptions that Co. M received throughout their journey also contributed to their sense of mission. At Aurelia, a few miles east of Cherokee, Co. $\mathrm{M}$ found the band out and a large number of people waiting to bid them Godspeed. At Fonda and Manson schools, children were out in force with little flags and bouquets of flowers and sang patriotic songs. At every town crowds gathered at the depot and waved and cheered as the troop-train passed through.

A reporter for the Register covering the arrival of the "Cherokee boys" at Des Moines described them "as lively a band of Indians as ever carried the name." They impressed him with a yell that good patriots would hear at every train stop between Des Moines and Chatanooga. They rolled it out on the air with all the vim of a college football team:

Cuba, Cuba, bow, wow wow!

Liberty! Liberty!, chow chow chow

Vengeance, vengeance, down with Spain

Iowa, Iowa, remember the Maine!

Such enthusiasm was diminished only slightly when the Cherokee volunteers were made aware that in a military sense the United States was entirely unprepared 
for war. At Camp McKinley on the State Fair Grounds they encountered for the first time that which was to be their real enemy - the incredible disorganization and mismanagement of the war effort. "Captain Kreger's Farmers" joined the other Iowa troops sleeping on straw in the animal stalls of the fairgrounds. But each company had "a cattle barn to itself," as Gillette wrote home on May 3, 1898. The Des Moines' State Register complained that "a slight expense of lumber and nails" would at least help to keep the soldiers "free from vermin."

The month at Camp McKinley passed quickly. By the middle of May only six of the 3000 men at Camp McKinley were sick and none of them were from Co. M. Thousands of patriotic citizens visited the camp each weekend. Soldiers who were willing to hazard uncertain streetcar transportation back to the fairgrounds could go into Des Moines on pass in the evenings after dress parade. When Peg McFadden came down from Cedar Falls to marry Charley Roddis, a number of men from Co. M attended the wedding. At a "shivaree" for the newlyweds a few evenings later the groom presented a box of oranges to the men of his company.

During the last week in May, Co. M, now part of the Third Batallion, 52nd Iowa Volunteers, passed in review before Gov. Leslie M. Shaw and his military cabinet. On May 28, troop trains rolled southward toward Chickamauga Park, Ga. The Cherokee Times reported the journey of Co. M. Four bands, hundreds of people, fireworks and cannon greeted the train at Marion, Iowa. The "Wagner sleeping cars" had pleasant berths. In Chicago they stopped at the Union Stock yards where the horses were taken out, watered, and exercised and the men ate breakfast "with the sweet fragrance of a hog pen floating in the window to season their victuals." From the young ladies along the route, soldiers gathered a collection of hat pins, shirt waist pins and stick pins. The rail fences of the south and the old style farm houses with fireplaces and big brick chimneys interested the boys from the Midwest. They noted the monument to Henry Clay in the 
distance as they moved through the famous bluegrass country of Kentucky. Entering Lexington they were literally covered with flowers thrown at them by hundreds of people lining the tracks. The 297-foot-high bridge just outside Lexington fascinated them as did the first several railroad tunnels. When they stopped at a small mining town in Kentucky, the troops inquired about newspapers. "They don't know what they are," one soldier wrote home. "Dead to the world herel" After Ohio this came as a shock to him.

At Lebanon, Ohio, an enormous crowd had converged at the depot to greet the Iowa troop train. Lebanon's Daily Reporter gave the event front page coverage.

The crowd was twice as large as had assembled on any previous occasion. The band stationed on the top of a convenient boxcar played "Marching Through Georgia." No such enthusiasm has ever been witnessed here before. Pretty girls were out in force and showered the boys with flowers ... ladies with baskets well filled with dainty eatables passed them to the hungry boys in the cars. The boys were finer looking than any that have so far been seen here. They lacked the rough features of the others and seemed to come from the very best homes in Iowa .... As the train pulled out many of the ladies in the crowd cried as if some of their dearest friends were leaving home. . .

Fifty-two hours after leaving Des Moines, Co. M arrived in Chattanooga. The first night they slept aboard the train. The view of Lookout Mountain impressed everyone the following morning. The Iowa boys knew their Civil War history. "No wonder the rebels commanded respect, from the command they had of the surrounding country," Gillette wrote home about Lookout Mountain. He noted and described the famous Missionary Ridge outside Chattanooga and the statue of Gen. Henry Thomas, the "Rock of Chickamauga," waiting to greet the Iowans as they pulled up the hill near the center of Chickamauga Park.

At first the old historic field of Chickamauga, a densely wooded park of some seven thousand acres, seemed to be an ideal camp ground. Gillette told the folks in Cherokee about the "immense water pipe that runs down through the center of the park, furnishing an ample supply of excellent water for the fifty regiments . . . encamped on either side," 
and about his outpost duty guarding the springs that supplied the camp with water. Then when someone poisoned the spring a short time later, a New Yorker was arrested as a spy for the Spanish.

The Iowa troops found some relief from boredom by excelling in troop review. On several occasions their performance prompted comments such as that appearing in the Chattanooga News on Aug. 10:

The regiment making the best showing of any was the 52nd

Iowa. Its lines were straight as arrows, its maneuverings fault-

less and the step and time of its men perfect as clockwork.

The men were of splendid physique and the vigor of their execution won for them the plaudits of all.

What had not been reported locally or back at home was that the Iowa volunteers were on the losing end of a battle for good health. Just a few days after their arrival in Georgia, dysentery immobilized many Iowa boys. Their weakened bodies could offer no contest to the typhoid fever germ that attacked next.

Of the four Iowa regiments, Col. W. B. Humphrey's 52nd suffered the severest losses. No Spanish adversary would inflict such casualties. Courage and staying power were not tested under fire, but under conditions where sanitary precautions basic as those laid down in Deuteronomy were ignored. Instead of blasting the Spanish out of the Hemisphere, Gillette spent a miserable three months in Georgia. One Co. M man, Roy Converse, died at this time in Georgia.

The ravages of typhoid soon hospitalized most of Co. M. Sergeant Gillette remembered the open latrines, the unboiled water, the "transport of quarters of beef on trays so covered with bluebottle flies the meat was scarcely visible." Within a month after their arrival at camp, when Co. M turned out for drill, only seventeen of one hundred twenty men had the strength to line up.

The Iowa volunteers were among the best-equipped units in camp. A Cherokee soldier, soon after arriving in Georgia, wrote home that "owing to our good equipment our colonel thinks the 2nd will be moving south soon." Each day brought new rumors about going to Puerto Rico, but nothing hap- 
pened. The repeated disappointments and prolonged inaction began to tell upon both officers and men; the sickness that had at first demoralized now produced outright despair.

A determined Sioux City mother who went down to Georgia to check on the conditions for herself insisted that the troops be moved. “. . . brave as these men are, they are beginning to quail before the advance of the insidious germ which hides in every dewdrop and lurks in every breath of air," she wrote in the Sioux City Journal. "Our hospitals are regular death traps," wrote E. H. Ryan of Sioux City's Co. H. "If you ever go into one you never come out alive."

Ryan wondered if "it is cheaper for the government to bury a man than to send him home?" The only hope for the Iowa boys was to get out of the "hell hole," away from "certain death." He wrote home about helping at the hospital. "Men are crowded in who are not able to care for themselves, so they just have to lie there. I have seen them left in the filth until their whole bodies were covered with maggots."

The Chattanooga press blamed the conditions at the camp on the soldiers' carelessness, but a Chattanooga citizen, after looking at the camp, declared that some of the army officers and surgeons ought to be in the penetentiary. "They have committed murder," he wrote.

Irate Iowa citizens exerted so much pressure on Governor Shaw to do something that he journeyed to Georgia for a personal inspection of Iowa troops and their camp. The Iowa boys insisted that the officer's carefully arranged tour of Chickamauga prevented the good Governor of Iowa from seeing how bad conditions really were. Governor Shaw told reporters that he was not completely satisfied with the facilities he had looked at and that he would do all he could for his boys. In the meantime, the Governor assured the folks back home, the Iowa troops "at least ... had good water." A private from Co. M retorted, "The only water the Governor saw was at the Colonel's tent where a large bottle is on ice. We drink water as yellow as the thickest water in the Missouri."

On Aug. 16, 1898, the men of the 52nd Iowa Volunteers petitioned their Governor: 
We are willing to die, if need be, in active service, but we do not wish to die as our boys are doing now, like dogs, of typhoid fever and lack of medical care.

When the state of Maine sent a special train to carry their sick home, Iowa troops hoped and prayed that their state would do the same. In a letter home to the Times the men of Co. M asked, "Where is Governor Shaw with his promises?"

Governor Shaw and concerned Iowans had not been idle. Although many at first placed more confidence in what high officials in Washington said than they did in newspaper stories, the time arrived when Iowans could no longer shut their eyes to the terrible conditions in Georgia. They were tardy, but they acted! On Aug. 18 a special train arrived in Georgia to bring the Iowa boys home.

Only three months had passed and now Co. M arrived back in Des Moines decimated, demoralized, and ill. It was 7:00 P.M, Aug. 30, when the troop train pulled into the Burlington depot. The soldiers who could, "fairly danced with joy when they stepped off the train," the Des Moines Leader told its readers, "their sunken eyes, hollow cheeks, faltering steps, and yellow skins gave evidence of their ordeal."

On Sept. 15, soldiers of Co. M who were able to walk began thirty-day furloughs. At Cherokee the town band and a great crowd of enthusiastic citizens assembled to give their soldiers a rousing welcome home, but only a few weary soldiers climbed off the train when it reached Cherokee at two o'clock in the morning. "Johnny doesn't come marching home," the Cherokee Times reported. "He comes straggling along — weak, weary, and sickly!"

Sergeant Gillette was one of the last to make it home. Gillette was big and strong and he had managed to stay well in the South, but back at Camp McKinley, the doctors had pressed him into service as an assistant in a hospital which had more than thirty typhoid patients in a room about thirty by thirty. The desperately ill men, burning with fever, were not allowed cool water or an ice pack of any kind. "The doctors thought such cooling would be fatal," Gillette recalled. During the days that Gillette served in the make-shift hospital he contracted typhoid fever inadvertently drinking from a 
water cup that was for the patients instead of the orderlies.

Somehow Gillette had made it back to Iowa, but the robustness that had characterized his entire life could not withstand the onslaught of typhoid fever. He spent six weeks in bed deathly ill. On Oct. 30, 1898 he ended his participation in what Secretary of State John Hay called America's "splendid little war." On that date, Sergeant Gillette was discharged and boarded the next train for Cherokee.

The tragic and seemingly useless deaths stemming from the Spanish American War made a profound impact on both the soldiers of Co. M and on the people of Cherokee. Martial music and the cheers of well-wishers were still ringing in the ears of the Cherokee soldiers when war had suddenly lost its glamor. As the dreadful typhoid felled the men of Co. $\mathrm{M}$ and death stalked the tents of Chickamaugua Park, home and community had taken on new and special meaning. The folks back home in Cherokee who had waved goodbye to a company of healthy and determined young men now found a very special place in their hearts for the ill and emaciated men - suddenly grown much older-who managed to totter back. The heartfelt respect and affection that the Cherokee community extended to the men of their "gallant Co. M" touched the life of one young man in particularSergeant Guy Gillette, who responded with a love and devotion for his community that grew deeper with each passing year. This mutual affection, that never diminished, was destined to be a significant part of Guy Gillette's life and an important element in his rise to national and international prominence.

Personal

Bibliography Manuscripts

Gillette, Guy Mark, MSS

The Gillette MSS are located in Cherokee, Iowa and Northridge, California. Unfortunately much of the MSS were destroyed after Gillette's defeat for re-election to the United States Senate in 1954.

Personal Interviews and Statements

Gillette, Guy Mark. Statements received at various times from 1966 to the present. Personal interviews, 1965, 1966, 1967, 1968.

Congressional Record

Documents 
Report of Assistant Inspector General, Iowa National Guard, Adjutant-General's Office, February 19, 1895.

Who's Who In America

\section{Newspapers}

The Chattanooga (Tennessee) News

The Cherokee (Iowa) Democrat

The Cherokee (Iowa) Herald

The Cherokee (Iowa) Times

The Des Moines (Iowa) Iowa State Register

The Lebanon (Ohio) Daily Reporter

The Omaha (Nebraska) Bee

The San Francisco (California) Chronicle

The Sioux City (Iowa) Journal

The Sioux City (Iowa) Tribune

\section{Secondary Works}

Auxier, George W. "The Propaganda Activities of the Cuban Junta in Precipitating the Spanish-American War, 1895-1898," The HispanicAmerican Historical Review, XIX (August, 1939).

Bernard, Harry. Eagle Forgotten: The Life of John Peter Altgeld. Indianapolis: Bobbs-Merrill, 1938.

Cole, Cyrenus. Iowa Through the Years. Iowa City: The State Historical Society of Iowa, 1940.

Commager, Henry Steele. The American Mind. New Haven: Yale University Press, 1950.

Freidel, Frank. The Splendid Little War, Boston: Little Brown and Company, 1959.

Hofstadter, Richard. Social Darwinism in American Thought. Philadelphia: University of Pennsylvania Press, 1944.

Kennan, George F. American Diplomacy 1900-1950. Chicago: University of Chicago Press, 1951.

Lindsey, Almont. The Pullman Strike. Chicago: The University of Chicago Press, 1949.

May, Ernest R. Imperial Democracy: The Emergence of America as a Great Power. New York: Harcourt, Brace and World, 1961.

Mills, Walter. The Martial Spirit. Boston: Houghton Mifflin Company, 1931.

Pratt, Julius W. Expansionists of 1898. Baltimore: The Johns Hopkins Press, 1936.

.“The Large Policy of 1898," The Mississippi Valley Historical Review, XIX (September, 1932).

Wilkerson, Marcus M. Public Opinion and the Spanish American War. Baton Rouge: Louisiana State University Press, 1932.

Wisan, J. E. The Cuban Crisis as Reflected in the New York Press. New York: Columbia University Press, 1934.

Grateful acknowledgement is made to Marguerite Whiting of Cherokee, Ia. who was so kind to loan us the use of the photographs of Co. M. for the "Gillette" article. The photographs are originally from the historical collection of Mrs. Whiting's father, N. L. Stiles, and are now in her possession. 
Copyright of Annals of Iowa is the property of State of Iowa, by \& through the State Historical Society of Iowa and its content may not be copied or emailed to multiple sites or posted to a listserv without the copyright holder's express written permission. However, users may print, download, or email articles for individual use. 